\title{
Designing leadership chairs: Experiments with affirmative critique of leadership and environmentality
}

Malou Juelskjær, Aarhus University Malou@edu.au.dk

Dorthe Staunæs, Aarhus University dost@edu.au.dk

\begin{abstract}
:
Through a methodology of having students 'design' leadership chairs, we investigate how contemporary leadership and governing operate by orchestrating affects and strategically shaping the physical environment in order to transform and shape intensities, desires, atmospheres, and social relations. By presenting a pedagogical framing as 'a posthuman sensorium', with its design of leadership chairs and art of conversation, we invite engagement with dilemmas and problems of contemporary organizing processes as a careful affirmative critique.
\end{abstract}

Key words: Psy-leadership, affectivity, governance, leadership, non-human agency.

\section{Introduction}

Advanced capitalism, with its focus on the human workforce as a "capacity for invention" (Thrift, 2008a, p. 115), effects intensified ways of leading learning capabilities, mobilizing creativity and innovation, and grooming 'talent'. Often, this sort of leadership operates by orchestrating affects as well as strategically shaping the physical environment: The spatial arrangements and materialities are enacted in order to transform and shape intensities, desires, atmospheres, and social relations. This may be termed 'environmentality' (Foucault, 1991; Massumi, 2009). Environmentality is a term for the orchestration of the affective-material environment with the intent to indirectly vitalize the capacity of perception, cognition, and affectivity (Juelskjær \& Staunæs, 2016). In this sense, leadership/management becomes constitutive of an intractable tension, a paradoxical logic, where producing and breathing life into certain feelings and affective states of mind somewhat overrules or subdues other affective states of mind as a constitutive part of this - complex - situation (Staunæs \& Juelskjær, 2016).

In order to move beyond either fully endorsing or rejecting this sort of organizing, we propose engagement with affirmative critiques (Braidotti, 2013; MacLure, 2015; Raffnsøe, 2016; Sedgwick \& Frank, 2003; Sonderegger \& de Boer, 2012; Staunæs \& Juelskjær, 2016) and diffractive readings (Barad, 2007). In this article, we investigate experiments where participants (who are positioned as educational leaders and 
managers in their professional lives) in a master's course on educational leadership designed 'leadership chairs'. As we will show, this is a method of evoking bodily- affective and conceptual understandings of new forms of leadership and environmentality, as well as their effects. Approaching affectivity allows us to gain access to the level of intensity: the level of life that concerns force, tension, charging, as well as the capacity of touching and moving and of being touched and moved. Affectivity is a concept of thresholds and entanglements. It dissolves settled binaries and boundaries, and it involves and transgresses phenomena such as body as well as language, matter as well as signs, humans as well as non-humans, content as well as form, drama as well as everyday life, ontology as well as epistemology. Brian Massumi claims that affectivity is autonomous (Massumi, 2002) but, despite having been inspired by his authorship, we disagree. Rather, it is our belief that affectivity has a determining influence and works in an irreducible manner, but always through and entangled with other forces. In this sense, affectivity becomes transhuman (rather than human), trans-personal (rather than pre-personal), and multi-sensual while circulating and transforming situations, humans, and non-humans (Blackman, 2012; Brøgger \& Staunaes, 2016; Clough, 2007; Juelskjær, 2013; Juelskjær \& Staunæs, 2016; Staunæs, 2012; Staunæs \& Hvenegaard-Lassen, 2015; Staunæs \& Kofoed, 2015; Staunæs \& Pors, 2014). By materializing the leadership chair and the presiding over the (affective-material) environment, the experiments opened up (new) questions and facilitated the participants' reconsideration of leadership, learning, and ethics in light of advanced capitalism and environmentality. In this article, we analyse these experiments as sensuous and aesthetic encounters, opening up un/certainties and in/stabilities of intractable tensions and paradoxical logics of leading (self and others).

\section{Writing this article}

First, perspectives on contemporary leadership, as presented to and studied by the participants, will be briefly outlined. Hereafter, the methodology of producing leadership chairs will be framed as an experimental sensorium (Juelskjær, 2016) that conditions the potential of evoking senses, affects, and considerations concerning leadership. The experimental sensorium thus draws upon and transgresses the experiences of ancient educational settings for leaders, such as the mirror for the prince and the later reflective spaces for leaders (Staunæs \& Raffnsøe, 2014). By sensorium, we are occupied with cultivating the 'faculty of sensing'. Furthermore, we conceptualize the sensorium within a posthuman frame, where sensing is not an individual nor exclusively human affair (Barad, 2012; Juelskjær, 2016). The actioning of this conceptualization in our teaching requires some explanation before we move on. The pedagogical aim of designing and discussing 'leadership chairs' in a master's course is to produce a sense of the specificities of the varied intra-actions (Barad, 2007) taking place in situations of leadership and to consider, meet, and feel possible effects hereof. The design process facilitates movements in thoughts, feelings, wonderings, and questions that, in turn, enable the participants to become different, imagine, discuss with and of the faculty of sensing through the sensorium. Note that the design process is not about designing an 'actual chair'; it is about materializing 'chairing' and leading. The chair functions as a mode of opening for thinkingfeeling about chairing, governance and leading reflections through drawing, visuals, models, video, explanations of the qualities of the design etc.

The choice of a chair as the point of departure for thinking and feeling about the matter of governance and leadership is, of course, no coincidence. A chair is a place for resting; a technology of comfort (Juelskjær, 2009) allowing body and mind to sit down, dwell, and think. However a chair is also an enactment, a possibility of chairing. A chair intra-acts with and affects the world in particular ways - often depending upon how it is related to and entangled with the surroundings. A chair enables certain perspectives. It lifts the seated above the floor. Perhaps as with the pulpit, it lifts us above the heads of others to an elevated position from which it is possible to preach to and survey the crowd - just like the old professorial chairs in 
academia, and still symbolized in the act of an inaugural speech by a professor, president, or chairman of a parliament. A chair symbolizes power, position, and perhaps life itself (Nottberg \& Persson, 2000). Who wants to be placed in a high chair beyond the age of three? Who does not recognize the feeling of being excluded when there is not enough chairs for everyone? Who wants to be seated in a tiny, soft chair in which you become minor next to tall, hard chair - as once happened to a Turkish president while visiting his Greek counterpart? A chair also symbolizes possessions. Power is symbolized through the design of the chair. For instance, the almightiness of the throne is architecture through the use of fabrics, precious metals, and jewels, and it may present legends princes, kings, and emperors through chair legs made of the horn of a unicorn or tooth of a narwhal, and not least the lions guarding the emperor or king on each side. The chair shows us the manager and his/her powers, the time and culture of the power, may it be designed as Putin's remarkable chairs or a still trendy and modern Eames chair in Don Draper's office. A Game Of Thrones is but one example of battles to chair the world and ending with the chair and ceremony of coronation of the prince, king, or emperor - or even just a leader of an educational institution. A chair is a vivid corporate fiction (Staunæs \& Søndergaard, 2006); a well-chosen figuration allowing us to think and fantasize about the material-semiotic-affective of which governance and leaderships are made. To invent new chairs is to daydream of how governance and leadership may be different. "To daydream. It is to play games with realities. To invent forms of social-science fiction. It is to find ways of telling stories that make realities look a little different. Realities about organizations. Realities about managers" (Law, 2003). Daydreaming about new chairs may reconfigure not only the manager and his/her powers in the traditional way, it may even broaden the perspective of affects and senses involved in the more-than-'the Leader' and more-than-human aspects of leadership and governance.

As we move on with this article, we will invite the reader into the sensorium as we present discussions and tensions that were evoked in class while participants and teachers investigated and discussed the chairs. We wrap up by considering the potentials of affirmative critique in the process (and aftermath) of designing chairs. Writing about the material-semiotic-affective creations, the fragile sensing of complexities, and 'advanced working life' calls for writing styles that break open and invite the reader to tap into some sort of sensing apparatus, a way of becoming-reader of-and-with the experiment, As such, the presentation of the chairs that the participants made and the analysis of these chairs and of the discussions in class employ a somewhat different style of writing than the rest of the article (elaboration will follow).

\section{Contemporary material-semiotic-affective (!) leadership}

Within advanced capitalism, human competences, potentials (and talents) - have long been in focus as a resource of Human Resource Development, and thereby as key to organizational and societal 'growth' (Thrift, 2008a). Concordantly, there is a vast and inventive field of managing and developing human resources through technologies, techniques of opening up and directing "how"; that is, to what extent, in what manner, and with what passions one, as an individual (be it employees, leaders, participants), relates to oneself while/through relating to one's work. As stated and analysed within contemporary management studies, leading self-leading employees has thus become a dominant leadership skill. As opposed to the growing literature on self-management and the management of self-management, which is aimed at increasing performance (Manz, 2004; Neck \& Houghton, 2006), the point for critical studies of managing self-management is to intervene with governmentality studies (Foucault, 2010; Foucault, Burchell, Miller, \& Gordon, 1991; Raffnsøe, 2010; Åkerstrøm Andersen, 2009). In these studies, the production of subjectivities is seen as an effect of discursive power (Rose, 1996; 1999), technologies of power (Dean, 2010), discursive orders and patterns of the normative (Fleming, 2003), and affective patterns of the normative (Staunæs \& Bjerg, 2011). They also show how the development of selves is entangled in 
organizational values and norms, and moves from outer to inner spaces of the Self (Knights \& Willmott, 2002).

Theoretically, one could view the management of self-management as a type of managing, where competences are no longer something externally given (skills to be learned and used), but rather something emanating from the employee's ability to "double oneself as a resource of competence" (Bramming \& Andersen, 2016 (in process)). Or in other words, the employee's capacity is a capacity of ever becoming more - becoming a walking, talking (human) potential. As a potential, it becomes pivotal for the organization, and therefore the leadership practices, to establish a pedagogical relation with the employee, as a pedagogical relation may be sensitive and eager to assist in moving the employees (individually and collectively) beyond the present state of being and into the next. The concept of "affective labour" is an example of an entry point for studying the practices and consequences of this focus on human resources:

[By 'affective labour'] I am pointing to what might be called the 'vitality' of workers, their passion for the job and their ability to order their passions in order to do the job well, and most especially the innovative energy that can be unlocked within and between them: potential is redefined as emergent potentia and it is this potentia which is being bought and sold under the name of 'talent' [...] business is trying to draw on the affective standing reserves of humanity without triggering negative tacit qualities like prejudice, poor practice, or uncritical or wayward intuition: qualities like passion, energy, and a kind of aesthetic judgement of the situation which is crucial to the conduct of economic life. (Thrift, 2008a, pp. 120-121)

With this practice of enhancing the learning of employees (and participants), we see a specific governance of the potentials of individuals that has invited in a whole range of technologies and techniques of leadership stemming from, and relying on, the psy-sciences (Juelskjær \& Staunæs, 2016; Rose, 1999). It is psy-leadership (Staunæs, Juelskjær, \& Knudsen, 2009). Technologies and techniques inspired by the sciences of psychology, pedagogy, and psychiatry are exactly of the kind designed to open human capacities, to set free intensity and excitement, all the while one senses that and how one becomes different, learns differently, and is otherwise capable of more - either alone or with colleagues. As Thrift (2008a) mentions in the passage quoted above, it is an art of leading that (seeks to) trigger passion and energy 'in' the employee and bypass "negative tacit qualities" (ibid.), as these qualities may lead to a decrease in productivity and creativity. Such triggering of productivity and creativity goes on through the entire setup of the working life, as well as partly beyond 'pure' cognition, and some of these modes of governing and leading can therefore be analysed as a form of orchestration of the environment, calling for the concept of 'environmentality' (Foucault, as cited in Massumi, 2009).

Environmentality is an expansion or a specific twisting of the concept of governmentality. Governmentality fuses governance with mentality and is the art of government as such: a set of strategic ways to act on others' actions; a social technology of power through governing mentalities (Foucault, 2010; Foucault et al., 1991). As we have suggested elsewhere, the concept of environmentality similarly contracts environment and mentality, pointing to the forces of the environment (environment in the sense of nature, culture, and naturecultures) in producing and shaping mentalities.

We define environmentality as an orchestration of the physical milieu as well as the social atmosphere with the intent indirectly to vitalize the capacity of human perception, cognition, and affectivity. Environmentality is a specific sort of governing, which manages the intensities instead of the identities and does so through modulations of the environment and by facilitating possible fusions, openings, and connections-in order for the participants [or employees] to continuously 
transgress and develop. It is potentializing what it may become. (Juelskjær \& Staunæs, 2016, p. 188)

The concept of environmentality directs our analytical attention to the more-than-human and to what Brian Massumi (2009, p. 167) has termed "onto-power": the indirect shaping of life.

Governance and everyday leadership technologies turn into strategic endeavours to capture, generate, and maintain affectivity through the expanded agency of environment(ality) in order to enhance the capacities and capabilities of employees. To become a leader of these more-than-human leadership practices is risky business: You may lead with potentiality (or 'potentia'), but you cannot control or steer 'it'. When leading to trigger passion and energy, the leader may not know when/if the employee will encounter burnout or exhaustion or when/if negative tacit qualities show up anyway. Affectivity is always on the edge, always on the move (Massumi, 2002). One moves with forces that may take the leaders, the employees, and the organization in many directions (Clough, 2007; Juelskjær \& Staunæs, 2016; Thrift, 2008b) and not necessarily only positive ones.

\section{'Leadership chairs' as a prism of the more-than-human of leadership}

The indeterminate character of psy-leadership (the specificities of the leading through material-affective psy-technologies, designed to open human capacities) is exactly what was addressed in the master's degree course when the participants worked with designing 'leadership chairs'. As already expressed at the beginning of this paper, it is not a coincidence that we used the methodology of producing leadership chairs in education courses on 'the psy-management of leadership'. Chairs and leadership have a long and entangled history. There are further theoretical arguments to be made - both about leadership and chairs and about their material, spatial, and affective qualities. Working with leadership chairs highlights the material quality of leadership. Orlikowsky (2007) argues, with regard to studies of technologies in organizations, that one should not state the materiality of organization as something 'special', thereby indicating that organizations are not themselves also a material practice: "dealing with materiality as a special case [...] loses sight of how every organizational practice is always bound with materiality. Materiality is not an incidental or intermittent aspect of organizational life; it is integral to it" (Orlikowsky, 2007, p. 1436).

So leadership - being an organizational practice - is always also more than a human endeavour; it cannot be done without our non-human others taking an agentic part. But within everyday practices, we tend to see the person, the Leader, capital L, even though ideas of 'distributed leadership' have been around for decades now and propose that leadership is more than what stems from the Leader. Ideas and practices of distributing leadership (to teams, to employees with no formal leadership position, to social technologies and technologies of control/performance) are part of ordinary 'toolboxes' of contemporary leadership. Nevertheless, in the everyday doings of organizational life, the awareness of the non-human agencies tends to slide into the background when leaders analyse dilemmas and ascribe responsibilities for problems and solutions within specific situations. By working - within teaching and learning at the university course - with a 'chair' and the spatial arrangement of the chair in relation to a specific dilemma or leadership 'task', we open up the affective-material qualities of leadership - not the Leader - and we analyse (with the participants) how the leader becomes of the affective-material leadership arrangements.

The 'of' is a paraphrasing of Karen Barad's posthumanist theorization, 'agential realism' (Barad 2007); we are all of the world in its ongoing differential becoming (Barad, 2007). This means that there is 'no way out', no exterior position to retreat to, either as researcher or other - the world and we become together, we are inherently material-discursive, and the agencies of matter and materiality are not external to and 
separated from 'the human'. The point is not to align things and humans, democratically handing out agency to each part (Juelskjær \& Schwennesen, 2012, Barad in interview); it is the a priori inseparability of matter and meaning, things and humans. What we know as 'things' and 'humans', and the borders between and separations of these matters, come to matter through specific iterative intra-actions where agential cuts provisionally resolve what 'is' (Barad, 2007). The concept of intra-action is designed to coin the mutual constitution of entangled agencies; entities do not exist prior to, but emerge in and with intraaction. When we work with the leadership chairs, our pedagogical aim is for the participants to get a sense of the specificities of the intra-actions, the specificities of what comes to matter, and meaning in specific practices, specific wor(l)dings. This also means (re)considering the status of ethics. Ethics is built in, every step of the way; we cannot leave ethical considerations until the end. The term ethico-onto-epistemology (Barad, 2007) highlights the inseparability of ontology, epistemology, and ethics: The becoming of values and facts are cooked together as part of one brew, as Barad says:

Ethics is an integral part of the diffraction (ongoing differentiating) patterns of worlding, not a superimposing of human values onto the ontology of the world (as if 'fact' and 'value' were radically other). The very nature of matter entails an exposure to the Other. Responsibility is not an obligation that the subject chooses but rather an incarnate relation that precedes the intentionality of consciousness. Responsibility is not a calculation to be performed. It is a relation always already integral to the world's ongoing intra-active becoming and not-becoming. It is an iterative (re)opening up to, an enabling of responsiveness. (Juelskjær \& Schwennesen, 2012, p. 265, Barad in interview)

Finally, repeating what was already mentioned in the beginning regarding the concept of affect as used in this article (and that the participants are also presented with), affect is not a human possession, it is morethan and trans-personal; it flows and connects situations, humans, and non-humans. This also means that as psy-leadership works through and promotes and shapes certain affects, it can be difficult to grasp - you cannot 'simply' perform a semiotic analysis as something more and different is also taking place.

\section{Methodology}

Chairs as an example of mundane materialities (could also be couches, table-chair arrangements etc.) cofacilitate situations of relating, acting, and leading human capacities. Elsewhere we have termed these 'comfort technologies' (Juelskjær, 2009, 2014; Juelskjær, Staunæs, \& Ratner, 2013) to coin and to analyse their leadership 'potentials'. By the design process, we flip the situation or the process to prompt affects, thoughts, emotions - in collaboration with various participants. We have used the methodology of producing leadership chairs in several courses on 'the psy-management of leadership': In two single semester postgraduate courses with 'with master's students in educational psychology at Aarhus University, Denmark; in one international Ph.D. course on education, affect, and new materialism at the University of Stockholm, Sweden; and in one master's course on psy-management at St. Gallen Business School in Switzerland. Finally, the methodology was used at Aarhus University in a master's programme module for educational leaders. Within this article, we focus only on the material gathered during the latter. We do that in order to 'zoom in' specifically on how leaders sensed their own leadership and that of their fellow participants.

As already stressed at the beginning of this article, the methodology is not about producing an actual prototype for a chair to put into mass production. As will be elaborated in the following sections, it is about creating conditions of thinking-sensing psy-leadership through the method of drawing, choosing, or producing visuals, models, video, and explanations of the qualities of the design etc. It is a way of enacting and enabling an educational agenda in relation to leadership and management. And furthermore, through 
our note taking in some sessions, audio recordings in others, and gathering of the material produced by the participants (their PowerPoint presentations) in others, this is then the data we co-create with the participants, thereby enabling research through and on our teaching practices: a research focusing on what is actually evoked by this methodology, and what that enables us (teachers, participants, researchers) to think.

\section{A posthuman sensorium}

One could call that which we (during the class) intend to create 'a posthuman sensorium'1 . The term sensorium comes from the Latin sensus: the faculty of perceiving. A sensorium is considered to be the totality of those parts of the brain that receive, process, and interpret sensory stimuli. The sensorium is the supposed seat (!) of sensation in the human brain; the place to which impressions from the external world are conveyed and perceived. Within a posthuman framing of the definition of a sensorium, of course, the faculty of perception, the borders of where the body ends and begins, is not given once and for all. Accordingly, the human of the posthuman framing is not a container, "Existence is not an individual affair" (Barad, 2007, p. ix), the senses are not a human possession, but of situated intra-actions (Juelskjær, 2016). So the pedagogical aim is for the participants to get a sense of the specificities of the intra-actions taking place with the practices entangled with the leadership chair - as they become, imagine, discuss with and of the faculty of sensing in the sensorium. Working with the (imagined) materials, shapes, colours, figures, and sounds is a work enacting visual, auditory, and tactile sensings - opening associations in numerous directions, both in a 'here and now', but also in messy ways opening to past sensuous/bodily experiences .

For a number of years, it has become common to frame teaching practices as a 'laboratory' (Staunæs et al. 2014, Raffnsøe \& Staunæs 2014), as a way to be innovative and experimental in relation to participants' learning ${ }^{2}$. What we propose with the posthuman sensorium is to change the foreground and the background of the perceptive registers, putting the senses at the forefront instead of (abstract) reflections. As we go with and through the senses, the meaning-making and analysis may take routes not as 'well-trod' and end up elsewhere, or at least with a slight change in the perception and understanding of the dilemmas investigated and discussed.

Further, we want to 'build in' a fluid or processual ethics - a sense of enabling response, attuned to the material-semiotic-affective productions and attuned to the specificities and the productions of otherness in that practice: For example, what is rendered in/appropriate by the ways of relating that specific choices of elements of the design may facilitate?

During classes, discussions were facilitated by the teachers with the ethics of diffractive investigation (Barad 2007). This entails reading 'through' instead of 'against' (i.e. comparing, judging) each other. Reading through and not against indicates not just being 'constructive' instead of judging and 'caricaturing', it is also a practice of paying close attention to differences that matter - and how they matter - precisely because of what (intra-actively) 'meets', and how. For example, how the specificities and differences of two different chairs enables a discussion of 'colour-blind leadership practices's. It is not a search for good/better chairs, but a reading through with the emphasis on the specificities that emerged through engaging with the different designs, metaphors, and dilemmas. Diffractive investigation makes a

\footnotetext{
${ }^{1}$ This definition of a posthuman sensorium is taken from Malou's paper at the NERA 2016 conference (Juelskjær, 2016).

2 See also http://www.phmetropol.dk/Forskning/Innovation+og+Professionsdidaktik/Uddannelseslaboratoriet+UDDX http://www.emu.dk/modul/filosofisk-laboratorium

3 'Colour-blind' in the sense that leadership can be 'blind'/'ignorant' to (power) issues in relation to diversity. We will unfold this in the analysis.
} 
difference. It involves continually being on the move with the diffractive patterns of shadows and light, so to speak. By working diffractively with the designs and discussions surrounding the leadership chairs, we draw on an experimental form of critique; we do not know in advance where and what critique will show up, we will have to see where it goes and do what we can collaboratively to open up nuances (as we will try to show in the way we write up the class session and its diffractive encounters of chairs and discussions and the analysis hereof).

In other words, through the methodology of designing leadership chairs ('activating' the visual, the auditive, and the tactile through the materialities, shapes, and colours of the chairs, intra-actively activating associations, thoughts, desires, ideas), we want to slow-motion the processes; we want to open up the sensing of tiny movements and to sense the agential cuts. We want to enable sensing - a slowing/accelerating/fine-grained awareness that is sensible to the non-human - the flow of affects, a learning of how we are of the arrangements and may possibly 'grasp' the multi-layered nature of the faculty of perception, open up for possibilities of arranging and changing arrangements in order to care about the relations. Instead of deconstructing, tearing apart, analysing, and scrutinizing, the participants begin by building up/assembling/constructing 'something'. The multi-layeredness is furthermore a temporal multi-layeredness: it is an invitation to reconsider past events of leading (and being led) and to reimagine possible futures. What we furthermore discovered during these processes of 'slowing down' and turning to the senses was that these techniques - and the constant insistence on them - in themselves became a source of inspiration for the participants in relation to their leadership practices: What valuable understanding about our practice and our employees are we missing out on with the high tempo of everyday governing and leading? Can we translate these techniques into ways of moving and leading?

\section{Pedagogical setup: What did we do?}

The participants worked in groups of three and started by choosing two leadership chairs from the art book "The leadership chair" ("Ledarstolen" by Jan Nottberg \& Hans Persson, 2000). The book contains images of chairs as works of art with metaphorical names (for example, "Divided loyalties", "User-friendly ambivalence", "Probationary dialogue"). The images were used to prompt thoughts and feelings about leadership among the participants. Following Michael White's witness method (White, 2008), the participants acted as interviewer, interviewee, or witness (with the observer of the interview taking notes of what went on in this session). In their groups, the participants interviewed each other about their associations concerning leadership and their senses of being lead. The participants were then asked to choose a specific situation/dilemma of leadership practices that involved psy-leadership and discuss this situation/dilemma. It was, furthermore, the teachers' hope that the images would trigger creative discussions of the possibilities of materializing dilemmas in and with a design. Having chosen a dilemma/situation, the process of producing their own chairs and spatial arrangement started - along with the further elaboration and investigation of the various nuances of the material-affective leadership practices. Theoretical and analytical concepts were put to work through designing and imagining - thereby 'tasting' the concepts for their helpfulness and asking: How can they assist us in analysing leadership? Where are we disabled by these concepts? When and where do we need other concepts? Every design was presented by the group and the dilemmas materialized were further (diffractively) investigated in plenum discussions. Materials were investigated and metaphors of leadership connected to the chairs were investigated and played around with.

We will now turn to (analyse) some of the chairs produced. They have been chosen as examples of the patterns that emerged. Characterizing the patterns (abstractly here, concretely exemplified and analysed below!): On the one hand, a cluster of chairs were designed by the participants to 'go with' the movements 
and the potentialities of a specific situation or work environment; to open and sense the atmosphere of the situation and consider how to cut connections and take care of relations. At the other end of the spectrum were chairs and arrangements designed to instil stability in an organization in flux and/or in relation to employees in flux/sensitive situations.

\section{Analysis of the posthuman leadership sensorium}

This section has two writing 'modes'. First, a chair is presented based on audio recordings and written notes from the presentations. Readers should be aware that the participants' presentations of the chairs and the design of the chair and its use are in themselves the result of their analysis of psy-leadership practices and of how to 'stage' them, and of the dilemmas of such practices. Following the presentation of the 'chair' is a section titled: "Further engagements - after the presentation of the chair". The style here is somewhat unconventional as it is a mash-up of 1) the discussions in class and the analysis that we conducted on site together with the participants and 2) a further theoretical and analytical threading of the discussions, conducted in the process of writing this article. We have decided not to stringently separate these two iterations as we find that there are not that many clear distinctions regarding what comes from 'where'; learning and knowing are processes that move continuously 'back and forth' and indeed did so in this case. So we have allowed narratives, metaphors, ideas, dilemmas, and questionings that the chairs produced to unfold - and then, here and there, we have made certain strategic demarcations.

\section{Example of a chair of 'opening and agility'}

As already hinted, patterns emerged when we looked at the different examples of chairs and dilemmas of psy-leadership of the arrangements: Some of the chairs had in common that they were designed for openness, movement, 'agility', connecting in situations between leaders and employees. Related to that design characteristic, discussions and considerations concerning the risks of 'over-exposure' and sensory and emotional exhaustion followed.

\section{Chair \#1 "the MUFO" (MUIti-functionality and UFO)}

The chair is presented via a PowerPoint presentation. An image of a slim chair on wheels 'flies in'. Images of specific components/qualities of the chair follow. They are components to be attached to the chair: A hand mirror, a small container, a backrest. Another chair module enters the scene.

The participants explain:

${ }^{4}$ The chair is on wheels, it must be able to turn 360 degrees so it is possible to view from all angles - even though there is always a back side. The chair must be able to adjust in height. It is an ergo-stool; to sit on it demands that the body is in balance because, as it is slim and agile, the body may otherwise fall off. We considered having needles sticking up from the seat so that sitting will not be very comfortable and you won't sit too long. But that didn't work as we did want the design to produce a comfortable and relaxed, active and self-reflexive leadership practice. The hand mirror is a metaphor of second order leadership [leadership practice where the leader reflects on the leadership practices, putting actions in the context of actions and investigating 'what is leading in this situation' (Andersen, 2004)].

\footnotetext{
${ }^{4}$ The font is changed in order to 'mark' the presentation of a chair.
} 
The chair offers the opportunity to rest your back. But it is a movable, 'being-awake-seat', so rest is not a stable situation. Furthermore, there may also be a footrest - signalling 'I am on top of the situation, you may come to me'. There is a 'conversation-module' that may be attached - either in front of the leader-body or attached back-to-back with the leader's body. The container is for the leading of various affects - it can contain "tudekiks" ("crying biscuits"5), champagne, or whatever. The chair is designed to not exclusively lead on intensities and affects - that is why the container is there: in order to place or situate these issues specifically (in the container). Furthermore, the feature that the chair can adjust height (up and down) is a metaphor for the ability to be leading on the in- and decrease of intensities.

\section{Further engagements - after the presentation of the chair}

So far, so good. The chair has been presented, has presented itself, has become present and as such able to enter into dialogue with, concerning leadership. Not in order to draw conclusions or point at specific practices for the future, but in order to engage. What associations, thoughts, and imaginations does it open up for? Let's consider what sorts of chairing may be going on:

Leadership here is first of all not headstrong or one dimensional; it is emerging/testing.

The relations are only fixed or stabilized momentarily by way of plugging in or pulling out the various components of the chair. For example, it needs to be decided whether the bodies of the leader and employee should be face-to-face or back-to-back. When is that decided, how, and by whom? What may be the effects of such non-/negotiations? Nobody in the class has definite answers, but agree that the questions may 'sit' in the room.

It is agile leadership. Is there a risk of dazed and confused leadership, as an effect of all the movements around and around - the spinning of the chair? There is a need for a lot of grounding in order to cope with this sort of 'chairing'. Is this primarily a reactive chair - that moves with the sentiments of the organization - or can it also set directions? If you only move with the flow, then nobody knows where they are going and exhaustion may follow from the constant attuning to 'where are we?' It may produce insecurity for the employees if affects and sentiments are constantly in focus. In other words, it is not likely that the affects will stay in the 'container'/cupholder device, so to speak. A student suggests that maybe the affectcontainer device needs to be within range of both leader and employee - so that both can initiate the plugging and 'parking' of affects. And what would such a device or technology or practice 'be like' should one translate the metaphor into everyday leadership practices? In these ways, the design gets readjusted while the material-discursive-affective leadership practices of the chair-arrangement are investigated - all the while, the participants also relate to their own leadership experiences.

What does the hand mirror enable and disable? The habitual use and agency of a hand mirror is that you look at yourself - you are drawn to the image of 'you'. This may be compared to, for example, a rear-view mirror that makes you pay attention to what else is going on in fixed angles behind you, or a street view mirror that enables you to 'see around corners'. But is looking at 'oneself' in the mirror while talking with employees the best way to move sensitively in the situation - or do you risk getting stuck in your own vision; as the mirror only repeats 'the same' endlessly (in contrast to diffractions that enable attention to

\footnotetext{
${ }^{5} \mathrm{~A}$ "crying biscuit" is a Danish expression. You use this when indicating (jokingly) that someone should stop 'whining' about something and instead 'move on'.
} 
patterns of differences and the study of differences that matter)? So this comment in class metaphorically unpacking 'the mirror' - questions the idea of self-reflexivity and asks whether something else is needed for the leader to learn about the leadership taking place. How do you actually make yourself and the leadership you are (part) of response-able; that is, enabling response? (Barad, 2007; 2012) In other words, how do you open up for input that you did not expect and that does not mirror what you expected to be with 'in the frame'? Maybe you need to shut your eyes and direct attention to your ears or skin? And, while sensing otherwise, do you then grasp through which practices such response-ableness is habitually hindered, obscured?

Let's (in the moment of analysing the chair while writing this article) move in another direction and consider further dilemmas of leadership in advanced capitalism (Thrift 2008a). The name of the chair is "The MUFO" (MUlti-functionality and UFO). How are the chair and the chairing 'a UFO'? Might it be helpful to consider ideals or practices of leadership as 'from outer space'? What may be gained by analytically alienating or demonizing leadership like that? To actually consider it alien - to consider moments of radical otherness within organizations and processes of leading and being lead: How and when does leadership become alien to the persons that are affected by it (that is, both leaders and employees)? How are the 'hosts'/the earthlings enabled to sense and decode whether it is a friendly and generous visit, or perhaps a hostile takeover? What are the weapons used? How does the alien enter the flesh of the hosts, how does the radical other become part of you - harming you and inflicting harm on others by your actions? How to pull back and make the organization liveable once again? Of course, this line of questioning is somewhat 'far out', but embarking on the metaphor of the alien entering the flesh may open up a 'fresh place' to consider whether and how advanced capitalist work life 'enters you' or works as what Massumi (2009) terms 'onto-power'. This may open up for thoughts about how to deal with that condition - and how to lead with, or even on, that condition. In other words, it must be remembered that, with this methodology, our aim is the production of questions and sensing.

To take the metaphor of the UFO and twist it one more time: The im/possibility of the existence of the UFO (the chairing, the associations of what leadership must be able to do) opens further for a debate about not taking for granted what may be accomplished. When is it time to temper ambitions of what may be accomplished? Let's consider when it is time to 'abort ship' or cut the connection of the situation in order to reconsider (perhaps with the help of others) what is going on, what else is possible.

This leads to consideration of who and what is invited into the leadership practice and opens for considering the fragility and limitations of the arrangement - considerations that take us (the writers of the article) back to the classroom and the discussions we had there. Viewing the chair-arrangement, it appears close, intimate, small-scale, with few people: Not many bodies fit within the arrangement at the same time (as one participant remarked). With the mirror in hand, there is furthermore a dramatic reduction of what may be viewed, and thus a reduction in the scope/range of leadership (as another added). How about further distribution - which others (and not radical, alien others) may enter the scene - and by what means and what design interventions? Would it help to consider the space that the chair is placed in - to try to connect the chair with other material components - or even how the space of the chair is connected to other spaces, and by what means they are connected (walls, glass, stairs, bridges etc.). In other words, the surrounding environment can be considered more strategic for enhancing ways of manoeuvring/leading.

Finally, as an effect of the questioning, sensing, twisting, and turning of the design and the psy-leadership of the chairing, one student/leader reflects: "Isn't it in fact impossible to work as a leader who is working with potentiality? You don't know what you have done (what sort of leadership has been 'committed') until it has materialized into something, and then you will need to design a new chair in order to respond to the unintended effect of those very practices" (quote from participant, recorded in field note). 
Genre disclaimer: Hopefully, it is apparent to the reader that the conversations unfolded through sensing with the design, enabling the participants to imaginatively place (their own) dilemmas of leadership within the design. While placed in the design/the posthuman sensorium, it was possible to investigate what different ways of naming and handling the dilemma may open up for or close down - as well as investigate what specific chairing and psy-managing may demand of the individual leadership and leader-body. Whether tacitly or vociferously, the leaders/participants sense their own borders, fixations, limitations, and desires of becoming as they open up questions and ethics within this rather different and imaginative environment (once in a while leading to paralysis, as is the case in the comment from the participant just above this disclaimer). This will continue with the next example.

\section{Example of a chair of stabilization - and dilemmas of cultural blindness and closings}

At the other end of the spectrum, there were designs with the ambition of stabilizing leadership and/or leading through stabilization - which is not the same. Hereby, a different opportunity opens up in plenum: To sense (with) the dilemmas and ethics of leadership of organizations in flux. Interestingly (?), the groups that chose a dilemma of leading in flux chose already existing and reputable designs and worked on customizing and metaphorizing them. You could therefore say that the desire for stabilization may call for a design that you already rely on, which is already of a world you find helpful, even though moving with the already known may risk fixing your choices of stabilizing in well-known fashions. Let's have a look.

Chair \#2 "Steady as a hug"

An image of Nanna Ditzel's chair "\#83" is shown. The seating and the backrest are of dark blue wool. The chair is teak wood. Besides the image, the qualities of the chair are listed.

The participants explain:

We started with chairs in the creative area - soft and smart. But we moved away from that thought while discussing the qualities of leadership that we wanted build in the design. So we have two chairs, as leadership cannot stand alone. They are alike, symbolizing equality. The seating and the backrest are of wool - which is a heat regulating and self-cleaning material. The backrest is comfortable. So we are 'back to basics'. The chairs must be light, so that leadership is moveable, though not so light that it may be overturned. We did not want wheels - as we do not want anybody to 'take us for a ride' ("køre om hjørner med os"). The four K's [in Danish the four terms each begin with $\mathrm{K}$ ]: Comfort, communication, quality, complexity-reduction. The wooden chair is a sign of quality, a belief in the future and in the craft - the art of knowing one's craft. It must be recognizable: you should not be afraid when entering conversations about these chairs - you can decode the signals. Leadership here is also about patience: The chair enables you to lean back a little and wait. As the design of the chair is a half circle, it is a protective territory; there are no sharp edges, it is a good backrest and offers good functionality.

\section{Further engagements - after the presentation of the chair}

There is a certain value in choosing a design classic: The signalling of the recognizable, quality, structure, seriousness, and stability. However, there is a paradox in the design's invitation to lean back: Leaning back 
may be decoded (by employees) as an act of arrogance and distancing - so balancing the leader-body will be necessary.

The leader produced by these leadership chair processes may be one of relative comfort and competence: One who knows what she is doing and how. The design assists in setting an agenda that the employee may appreciate (the hand-built chair, the quality etc.). Thus, the focus can be placed on the conversation. There are limits, though. Maybe the stability shuts down too much for possible movements, freezes the processes: There are not so many possibilities of changing anything. Furthermore, one student noted, there is a fear of being run over or taken for a ride built into the design (the NOT of wheels): will this fear come across/be sense-able in situations of leading, and how might that co-produce the situation?

Let's go deeper into the fact that you offer a design classic. As it is a design classic, it may also signal a touch of arrogance. You enter the room with the chair, knowing/sensing that this is certified quality. But what if you do not know who the designer is? Do you then feel uncomfortable, ignorant, little - even belittled? So there may be a sort of inbuilt flaw or mistake in the design if the actual desire is to produce a sense of safety or reliability and comfort, also for the employee?! This focus on the flaws opens up for the ethical awareness of socio-cultural blindness: how to resist assuming a 'shared world', how to not project one's own aesthetics and values onto others, thereby silencing and fixing differences in well-established hierarchies?

Furthermore, it is a specific aesthetic standard - the standard of 'Danish handcrafted design'. Would a person, say, raised in an environment of Pakistani aesthetics know that a wooden chair is meant to be understood as high quality? So we may add cultural blindness or racial colourblindness to the blindness of the design. How do standards colonize moments of leading, or even colonize leading as such? What colours do standards have? What colour does leadership have? What is blindness as such? What standards do we want to stabilize and what standards could benefit from re-evaluation? What are the connotations of power and authority? Do we actually think that by doing 'the same' (placing everybody in 'the same Danish design chair'), we make equals of the employees? How do standards hierarchize and fix human subjects?

Again, the design of the chairs and the follow-up discussions prompt these kinds of thoughts. It materialized consideration, which again affected and enabled the participants and the teachers to move in mind and bodies; to move the discussion and consideration of new forms of soft leadership, distributed leadership, and equalizing leadership into discussions of cultural specificities and how leadership intersects with sociocultural categories and normativities, eventually helping us into a norm-critical stance regarding the task of doing leadership.

If you become aware of the flaws, you may have the possibility of compensating for them/leading through the flaws: Mistakes are not to be avoided, but worked with, one might say. So what would that involve, ethically speaking? First of all, perhaps, it would mean building in friction against blindness.

When leading (in) an organization where leaders and employees have a sense of 'flux' or radical instability, considering and developing agents of stabilization may be an important task. However, careful attention must be paid to the specificities of the stabilizing agents: Where is stability placed? What become the expected effects of specificities of stability agents? Does stabilization mean that no further attention and questioning are directed towards the agencies of stabilizing? And what may happen when we look the other way? (One may play with considering what are the specific effects if stability is placed in 'the national', 'the masculine', 'the white', 'the coffee machine', 'the annual party', 'a weekly staff meeting', or 'the open plan office'?) 


\section{Diffractions and affirmative critique}

Learning about oneself as a leader - and learning about theories of affect and leadership - took place through the grasping of each other's designs, discussing them through one another, playing with arguments, and grasping theories through examining what the design and the situation/dilemma may imaginatively effect. We did not look for - or evaluate - 'better chairs'; instead, diffractive investigation made us keep moving with the 'patterns of shadows and light'.

One pitfall of the leadership chair design process was perhaps that the dilemmas the groups chose to focus upon tended to concern one-to-one situations between leader and employee and placed a lot of focus on the leader - albeit a leader that was of a material-affective design. Perhaps if we had been more specific about asking for design reflections on the relation between the chair and the wider spatial and organizational setting, then a broader view of the material-affective processes and (human and nonhuman) relations and agencies would have emerged. This could have opened for yet more nuances and entanglements with other times and spaces of experiencing leadership and its effects.

Nevertheless, we believe that the methodology has many merits. We find that it is pertinent to enable a sensing with and of the specificities of the intra-actions taking place in contemporary psy-leadership practices. To enable response. The methodology of producing leadership chairs/arrangements is, we are convinced, a manner of 'being in touch', where being in touch is to be "responsible and responsive to the world's patternings and murmurings." (Barad, 2012, p. 207). Working with design, imagination, sensing, we try to move beyond the well-polished critiques and solutions that leaders as participants in a master's degree course habitually produce and are taught to produce: That is, we do not (simply) want them to learn theories and concepts in order to reflect upon and critique at a distance their actual leadership practices. Nor do we want them simply to do classical 'headwork' - instead we want them to become sensitive to the sensorium that they are of in order to practise sensing-thinking while diffracting concepts and theories and everyday actions. In an essay on touch, Barad suggests that:

The force of imagination puts us in touch with the possibilities for sensing the insensible, the indeterminate, "that which travels along the edge of being, [that] is not being, but the opening of being toward" the other (Yusoff, "Insensible Worlds," n.p.) [...] helps us touch, the imaginings of materiality itself in its ongoing thought experiments with being/becoming. To do this is to touch on an ethics that is alive to the virtual. (Barad, 2012, p. 207)

It is not about designing the coolest chair or the perfect setup for a leadership practice (as if there was such a thing): It is not a quick fix. Experimenting with the designs and with sensing/imagining leadership from the designs opens a virtual space of hope, despair, tension, and agency in relation to one's own and others' leadership practices. And hopefully it opens up for sensing expanded agencies and ethics hereof - an expansion also facilitated by letting theoretical concepts (concerning material-affective psy-leadership) turn into metaphors and design elements. By letting theories become in touch with wor(I)dings. The processes are entangled and they are also entangled with senses of other times and spaces and might transform other times and spaces along the processes. Changes take place.

By presenting a pedagogical framing as 'a posthuman sensorium' with its design of leadership chairs and art of conversation, we invite engagement with dilemmas and problems of contemporary organizing as a careful, affirmative critique. An affirmative critique which is also ethico-onto-epistemological; it is teaching the leaders that ethics are not considered 'before' and 'after', but must be present, all the way through. A fluid or processual ethics - a sense of enabling response, attuned to the material-discursive-affective productions and to the specificities and the productions of othernesses in that practice. By slow-motioning the processes, we try to open up the sensing. The slow-motioning within the sensorium enables an 
awareness of the tiny movements and agential cuts - a slowing/accelerating/fine-graining sensing that is sensitive to the non-human, the flow of affects; a learning of how we are of the arrangements and may possibly sense the multi-layeredness of the faculty of 'perceiving', arranging, and changing arrangements in order to care about relations and bodies that may risk encountering exhaustion or collapse.

\section{And so}

If so desired, one may now reconsider the concepts of management, leadership, and appraisal. One may diffract concepts of guidance, mentoring, and/or counselling through the analysis of the leadership practices of the leadership chairs. May this produce new patterns of light and shadow? New questions? New sensibilities of the stakes - of the ethics? We hope so. Thank you for thinking with and against (becoming of) the sensorium.

\section{References}

Barad, K. (2007). Meeting the Universe Halfway: Quantum Physics and the Entanglement of Matter and Meaning. Durham, NC: Duke University Press. http://dx.doi.org/10.1215/9780822388128

Barad, K. (2012). On Touching-The Inhuman That Therefore I Am. differences, 23(3), 206-223. http://dx.doi.org/10.1215/10407391-1892943

Blackman, L. (2012). Immaterial bodies: affect, embodiment, mediation. Los Angeles: Sage Publications Ltd. http://dx.doi.org/10.4135/9781446288153

Braidotti, R. (2013). The posthuman. Cambridge: Polity.

Bramming, P., \& Andersen, V. (2016 (in process)). Selvledende organisering - flertydighedens organiseringsform i det moderne arbejdsliv. [Self leading organization - organizing modern work life] Frederiksberg: Samfundsvidenskab.

Brøgger, K., \& Staunaes, D. (2016). Standards and (self)implosion: How the circulation of affects accelerates the spread of standards and intensifies the embodiment of colliding, temporal ontologies. Theory \& Psychology, 26(2), 223- 242. http://dx.doi.org/10.1177/0959354316635889

Clough, P. (2007). The Affective Turn. Theorizing the Social. Durham \& London: Duke University Press. http://dx.doi.org/10.1215/9780822389606

Dean, M. (2010). Governmentality: power and rule in modern society (2. ed. ed.). Los Angeles: Sage Publication.

Fleming, P. S., A. (2003). Working at a cynical distance: Implications for subjectivity, power and resistance. Organization, 10(1), 157-179. http://dx.doi.org/10.1177/1350508403010001376

Foucault, M. (2010). The government of self and others. Basingstoke: Palgrave Macmillan. http://dx.doi.org/10.1057/9780230274730

Foucault, M., Burchell, G., Miller, P., \& Gordon, C. (Eds.). (1991). The Foucault effect: studies in governmentality : with two lectures by and an interview with Michel Foucault. Chicago, III.: The University of Chicago Press.

Juelskjær, M. (2009). "En ny start" : bevægelser i/gennem tid, rum, krop og sociale kategorier via begivenheden skoleskift. Ph.d.-afhandling. København: Danmarks Pædagogiske Universitetsskole, Aarhus Universitet.

Juelskjær, M. (2013). Gendered subjectivities of spacetimematter. Gender and Education, 25(6), $754-768$. http://dx.doi.org/10.1080/09540253.2013.831812

Juelskjær, M. (2014). Changing the Organization: Architecture and stories as Material-Discursive Practices of Producing "Schools for the Future". Tamara Journal of Critical Organisation Inquiry, 12(2), 2537. 
Juelskjær, M. (2016). Education architecture as a sensorium. bio/onto-power and leadership as entanglement. Paper presented at the NERA 2016, Helsinki, Finland.

Juelskjær, M., \& Schwennesen, N. (2012). Intra-active entanglements: an interview with Karen Barad. Kvinder, Koen og Forskning, 21(1-2), 10-23.

Juelskjær, M., \& Staunæs, D. (2016). Orchestrating intensities and rhythms: How post-psychologies are assisting new educational standards and reforming subjectivities. Theory \& Psychology, 26(2), 182201. http://dx.doi.org/10.1177/0959354316634217

Juelskjær, M., Staunæs, D., \& Ratner, H. (2013). The return of the Freudian Couch $^{\circledR}$ : managing affectivity through technologies of comfort. International Journal of Qualitative Studies in Education, 26(9), 1132-1152. http://dx.doi.org/10.1080/09518398.2013.816885

Knights, D. and H. Willmott (2002). 'Autonomy as utopia and dystopia', in M. Parker (ed.) Utopia and organization. London: Sage. http://dx.doi.org/10.1111/j.1467-954x.2002.tb03579.x

Law, J. (2003). The Manager and His Powers. Centre for Science Studies, Lancaster University, Lancaster LA1 4YN, UK, 1-6. Retrieved from http://www.lancaster.ac.uk/fass/resources/sociology-onlinepapers/papers/law-manager-and-his-powers.pdf

Manz, C. C. N., C. (2004). Mastering self-leadership: Empowering yourself for personal excellence. Prentice Hall.

Massumi, B. (2009). National Enterprise Emergency: Steps Toward an Ecology of Powers. Theory, Culture \& Society, 26(6), 153 - 185. http://dx.doi.org/10.1177/0263276409347696

Massumi, B. (2002). Parables for the virtual: movement, affect, sensation. Durham, N.C.: Duke University Press. http://dx.doi.org/10.1215/9780822383574

MacLure, M. (2015). The 'new materialisms': a thorn in the flesh of critical qualitative inquiry? Critical Qualitative Inquiry. G. Canella, M. Perez and P. Pasque. California, Left Coast Press.

Neck, C. P., \& Houghton, J. D. (2006). Two decades of self-leadership theory and research : Past developments, present trends, and future possibilities. Journal of Managerial Psychology, 21(4), 270-295. http://dx.doi.org/10.1108/02683940610663097

Nottberg, J., \& Persson, H. (2000). Ledarstolen. Stockholm: HLS Förlag/Högskoleförlaget vid Lärarhögskolan i Stockholm.

Orlikowski, W. J. (2007). Sociomaterial Practices: Exploring Technology at Work. Organization Studies, 28(9), 1435-1448. http://dx.doi.org/10.1177/0170840607081138

Raffns $\varnothing$ e, S. (2010). The obligation of self-management: The social bonds of freedom. Villum Foundation and Velux Foundation: The Annual Report, 26-63.

Raffnsøe, S. (accepted for publication). Critique and self-criticism. Outlines. Critical Practice Studies, vol. 17(2) forthcoming February 2017.

Rose, N. (1999). Governing the soul: the shaping of the private self (2. ed. ed.). London: Free Association Books.

Rose, N. (1996). Inventing ourselves. Cambridge: Cambridge University Press. http://dx.doi.org/10.1017/СBO9780511752179

Sedgwick, E. K., \& Frank, A. (2003). Touching feeling: affect, pedagogy, performativity. Durham: Duke University Press.

Sonderegger, R., \& de Boer, K. (2012). Conceptions of Critique in Modern and Contemporary Philosophy. Palgrave Macmillan.

Staunæs, D. (2012). Psy-ledelse: ledelse af/i uddannelsesorganisationer efter den affektive vending. Kvinder, Koen og Forskning, 21(3), 62-78.

Staunæs, D., \& Bjerg, H. (2011). Self-management through shame: uniting governmentality studies and the affective turn. Ephemera, 11(2), 138-156. 
Staunæs, D., \& Hvenegaard-Lassen, K. (2015). "And then we do it in Norway": learning leadership and Nordic whiteness through affective contact zones. In K. V. Rikke Andreasen (Ed.), Affectivity and race (pp. 77-94): Ashgate.

Staunæs, D., \& Juelskjær, M. (2016). The principal is present. Producing psy-ontologies through (postIpsychologies. In Z. M. Eva Bendix Petersen (Ed.), Interrupting the Psy-disciplines in Education (pp. 75-92): Palgrave Macmillan. http://dx.doi.org/10.1057/978-1-137-51305-2_5

Staunæs, D., Juelskjær, M., \& Knudsen, H. (2009). Psy-ledelse : nye former for (skole)ledelse set igennem tre optikker. Psyke \& Logos, Årg. 30, 2, 510-532.

Staunæs, D., \& Kofoed, J. (2015). Experimenting with affects and senses : a performative pop-up-laboratory (self) critically revisited. In C. S. Britta Timm Knudsen (Ed.), Affective methodologies (1. ed., pp. 4568): Palgrave Macmillan.

Staunæs, D., \& Pors, J. G. (2014). Affective methodologies. Thinking educational policy and management through (frictional) concepts of affects. In Kalervo, N. Gulson, Matthew Clarke, Eva Bendix Petersen (Eds.), Education policy, research and theories of the present. Hans Reitzel.

Staunæs, D., Nickelsen, N. C. M., Dupret, K., Adriansen, H. K., \& Høyrup, S. (2014). Læringslaboratorier og eksperimenter. In Dorthe Staunæs (Eds.), Læringslaboratorier og -eksperimenter (pp. 7-32). Aarhus Universitetsforlag.

Staunæs, D., \& Raffnsøe, S. (2014). Learning to stay ahead of time: moving leadership experiences experimentally. Management \& Organizational History, 9(2), 184-201. Retrieved from Staunæs, D., \& Søndergaard, D. M. (2006). Corporate Fictions. Norsk Tidsskrift for Kjønnsforskning, 3, 69-93.

Thrift, N. (2008a). A Perfect Innovation Engine: The Rise of the Talent World. Distinktion: Journal of Social Theory, 9(1), 115-140. http://dx.doi.org/10.1080/1600910X.2008.9672959

Thrift, N. J. (2008b). Non-representational theory: space, politics, affect. Milton Park, Abingdon: Routledge.

White, M. (2008). Kort over narrative landskaber (1. udgave ed.). Kbh.: Hans Reitzel.

Åkerstrøm Andersen, N. (2009). Power at play: The relationships between play, work and governance. London: Macmillan.

Åkerstrøm Andersen, N. (2004). Ledelse af personlighed: Om medarbejderens pædagogisering. [leading personality: the pedagogization of the employee]. In: Pedersen, D. (ed.): Offentlig ledelse $i$ managementstaten (pp. 241-267). Frederiksberg: Samfundslitteratur. http://dx.doi.org/10.1057/9780230239296 